\title{
The Fading of the Nation State
}

\author{
Wilfried Gerhard ${ }^{1}$
}

The end of the bipolar world compels us to look to the future, but it is a future that remains uncertain. Not only is it unclear in what direction the existing system of states is going to develop, but there is also uncertainty as to how the basic unit within that system - the nation state-is going to develop. To answer these questions, we need to examine the underlying principles of the modern nation state and the challenges with which these principles are at present confronted.

The modern nation state is based essentially on three principles: the principle of state territoriality, the principle of state sovereignty, and the principle of state secularity. All three principles are at present facing challenges that point to the existence of fundamental problems.

\section{Territoriality}

Ever since the Augsburg religious peace of 1555 and the principle of cuis regio, eius religio, which it formulated for the first time, territoriality has been a fundamental principle underpinning the modern nation state. "Territoriality" means a complete overlap between the area in which problems exist and the area in which those problems can effectively be solved. Until recently, the modern nation-state was able to fulfill these requirements; its political/legal range was greater than the social range of persons and groups acting within it. But since the advent of international terrorism and international organized crime, the development of new information and communications technologies and cross-border environmental pollution, the globalization of financial markets, and the rise of transnational economic players, the ability of nation-states - defined in territorial terms - to respond to these problems has been overtaken by the propensity of these problems to multiply.

\section{Sovereignty}

The second state principle-sovereignty-is also at present becoming increasingly problematic. State sovereignty in its classic form is being relativized by three innovative political structures. On the one hand, in Europe at least, supranational regimes are coming into being (governance over national governments); in the global context, on the other hand, we are to some extent experiencing the rise in influence of international regimes that operate with the support of states (governance with national governments), and to some extent, transnational regimes that function entirely without state support and cooperation (governance without

\footnotetext{
${ }^{1}$ Dr. Wilfried Gerhard is the Director for the Department of Social Sciences at the FührungsAkademie der Bundeswehr, Hamburg, Germany.
} 
national governments). Behind these innovative structures, all of which to some extent are making national sovereignty an outdated concept, a more fundamental process of political dissociation is taking place. At present, the linkage we have taken for granted in recent times between politics and the state is being loosened or even severed.

Why is this the case? In historical terms, a massive process of concentration of political power has been taking place ever since the start of the modern era. Initially this resulted in the creation of the nation-state; later, through a further process of concentration, in the imperialist state, and finally, in the bipolar bloc system we experienced during the Cold War.

Now, with the disappearance of the confrontation between these two blocs, an entirely new process of decentralization seems to be under way. Large political units are crumbling, as can be seen in the collapse of the former Soviet Union and Yugoslavia, and new national independence movements are leading to an unexpected increase in the number of state players. At the same time, the newly emerging political/state players are less and less able to find permanent solutions to problems that are increasingly global in nature. And so there is a need to establish international regimes and to recognize politically active private players, such as the many NGOs now in existence. The ultimate outcome of this development could be, on the one hand, the replacement of the sovereign nation-state with various forms of nation-states embedded in supranational structures and, on the other hand, a rise in public-private partnerships.

\section{Secularity}

In the context of state secularity and in an increasingly colorful, less homogenous (i.e., increasingly multi-cultural) society, nationalism in particular appears problematic at present. Waves of migration triggered by various different factors are bringing people across borders into other states, people who-if they remain permanently rather than just temporarily — need to be integrated into their new state's society. So the fundamental question is: what mechanisms does the secular state have to respond appropriately to that which is foreign and different, given that a nationalistic approach to integration is no longer acceptable?

\section{ON THE PRINCIPLE OF TERRITORIALITY}

\section{History of ideas: Jean Jacques Rousseau}

This first section on the principle of territoriality in the modern nation state, like subsequent ones, will open with an idea from a distinguished political thinker. Jean Jacques Rousseau explicitly articulated the problem of territoriality in its political dimension. His attempt to establish the requirements and preconditions for operating a form of direct democracy identified two political principles that are closely associated with the problem of territoriality: 
The principle of the small-scale economy. With this principle, Rousseau wanted to prevent a situation whereby the economic activities of citizens would transcend the political/territorial frontiers of the community, thereby potentially escaping political control. An economy based only on small-scale economic activity would ensure that the principle of political control of the economy was safeguarded.

The principle of the small-scale territoriality of the political units themselves. This principle, which he saw realized in the city-state of Geneva, was intended to make direct democracy-i.e., democracy as a way of life-possible.

In analytical, abstract terms, the principle of territoriality thus consists of two elements:

- The general political question of the territorial range to be covered by politics in order to ensure effective control of society.

- The specific theoretical question of the maximum geographical area over which democracy can continue to function properly.

The following remarks apply to both these elements.

\section{Political control as a "territorial problem"}

\section{The traditional view}

Historically, political control of the economy has not conformed to Rousseau's ideas. Even in the heyday of the nation-state, the economic activities of individual citizens in particular extended far beyond the political boundaries of the nationstate community in which they lived. However, the state traditionally had both the right and the means to secure the cross-border economic activities of its own citizens by adopting protectionist measures (e.g., currency and export controls) in the interests of the state as a whole and also, conversely, to regulate incoming economic activities on the part of foreign players by introducing quotas and customs tariffs. As a result, national control of the economy was retained.

Political control based on the principle of territoriality goes much further, however. As a political principle, the principle of territoriality is intended to enable the state not just to control the economic activities of citizens but also to guarantee control of internal and external security. Thus it is possible:

- To guarantee in a downward direction its precarious general control over its citizens (conditio humana).

- To regulate in an upwards direction its precarious control over international relations (conditio nationis). 
Control over one's own citizens. The first case largely concerns the problem of criminal behavior. The nation-state could assume, as a matter of course, that criminal behavior would be easily dealt with by a national police force. For this form of control to be possible, however, crime would have to consist largely of private, small-scale criminal activity.

Control over international relations. The second case mainly relates to wars between states. Again, the nation state could assume in the past that external threats would manifest themselves mainly in the form of violations of national borders. And it developed the armed forces as an instrument to combat such threats.

\section{Territorial challenges}

What changes have now been made to this traditional perspective? If we look at the present international scene, we see that we are confronted with challenges that systematically undermine the territorial principle of the nation-state in political/legal, economic, and ecological terms.

The political threat has largely shifted from the question of wars between states. But, rather than being replaced by an international global peace order, it has been succeeded by various forms of privatization of political violence, ranging from civil war to international terrorism. The measures traditionally taken by nation-states to prevent violations of their borders, typically through the deployment of military force, are no longer effective. When armed forces are nevertheless deployed-for example, in Kosovo or Afghanistan-they are forced to radically change the way they see themselves in political and professional terms as well as their possible rules of engagement.

The same applies to the next problem: the internationalization of private criminal activity (trafficking in drugs, women, and weapons). Nowadays, the territorial borders of nation-states tend to act more as an obstacle than as an aid to efforts to combat organized crime.

One entirely new challenge that is almost completely beyond the capacity of the territorial states to address is the growing number of ecological risks. The fact that pollutants can spread freely across borders, affecting wide areas, confronts the territorial state with hitherto unknown problems. Thus, for example, Australia is an almost grotesque example of the yawning gap between ecological cause and political/ecological effect, and is helpless in the face of a complete lack of ecologically effective national frontier controls.

The progress made in information technology and science has had a similarly huge impact on the territorial nation-state. The Internet and the "information superhighway" have essentially undermined all forms of territorial frontier. The virtual world of bits and bytes does not inhabit a physical space in which such boundaries would be either feasible or helpful. The new virtual space created by the Internet exerts an influence on the global economy and enables it to avoid the 
controls traditionally exercised by national economic policies. The exchange of data and information taking place in real time makes speculation on the international money market a political issue of the first order. The sums of money being shifted to and fro on this market with the aim of making profits for private players have reached proportions that render the attempts of national governments to support their economies by buying and selling currencies relatively ineffectual. Thus, totally private money transactions can, in extreme cases, cause the collapse of entire national financial structures, as was the case to some extent during the crisis in East Asia. Compared with this, the few border controls that still exist for the traditional exchange of goods appear positively archaic.

\section{Democracy as a "territorial problem"}

So far, these problems do not affect the theoretical question raised by Rousseau regarding democracy. This only happens when the question arises of how political control can also be democratic control. One has to start from the realization that here, too, history has moved beyond Rousseau's principle of direct democracy based on small-scale territories. Nowadays, many of us live in a representative democracy, and such a democracy has to cope with much more generouslydescribed frontiers. But, in principle, the question remains: How large can a state be for democracy to remain possible?

If democracy:

- At the cognitive level has anything to do with transparency of political processes and,

- At the emotional level has anything to do with a willingness to stand up for each other, to accept a shared political destiny and,

- At the pragmatic level has anything to do with the possibility of realizing one's interest in participation,

then it is perfectly clear that the territorial borders of a democracy can be larger than those defined by the nation-state, but in principle must be smaller than those defined by globalization. One can even formulate this as a principle: A political territory must not be so small that attempted political control of social problems is in vain, but neither must it be so large that democracy does not have a chance. The European project could be regarded as a test case here.

The question is, Is Europe, namely the EU, a political project that meets the quasi-conflicting requirements of political control that is cast as widely as possible and democracy that is as close as possible to the people?

The first related question is, Is the EU capable of realizing political control? The answer is, at least in principle, Yes, because the ability to exercise political control is initially a matter of being able to regulate bureaucratically. The so-called 
acquis communautaire, which contains 90,000 pages of regulations, has (at least so far) not come up against any bureaucratic limitations.

The second related question is, Is the EU capable of fulfilling democratic principles? That is to say: Is its capable of achieving transparency in decision-making processes, not just for bureaucratic insiders but also for the public at large?

Is it capable of creating a feeling of shared political destiny? This would be essential for the development of a European security and defense policy. Is it capable, for example, of motivating people in Northern Norway and Southern Italy to take joint action and stand up for each other?

Finally, is the EU capable of offering opportunities for participation that, for example, would enable a German to take part as a matter of course in the process of the formation of political opinion in France-in other words, to make use of his rights on the basis of feeling himself to be part of a European public?

If all these questions can be answered "Yes" only half-heartedly, then the territory covered by Europe is clearly too large.

\section{ON THE PRINCIPLE OF SOVEREIGNTY}

\section{History of ideas: Thomas Hobbes}

At the end of the medieval period, as the modern state began to emerge, the concept of sovereignty started to gain importance. Sovereignty is the formal right to make final decisions. With the gradual disappearance of a uniform Christian culture such as still existed in the Middle Ages, the question of this final right to decision-making authority naturally became increasingly important. The reason is that the validity of regulations and laws could no longer be justified by appealing to a concept of divine Truth. Binding truth was now replaced by binding decisions made by a secular authority, with the question of Truth being confined to the spheres of religion and science. Politics was liberated from Truth. Where politics still claimed to be based on Truth, it became ideology.

During the transition to the modern period, Thomas Hobbes formulated this notion in his famous dictum: auctoritas, non veritas facit legem. Auctoritas, however, became auctoritas precisely because it was able to make decisions without any competition. There could not, therefore, be any competition between regulatory authorities. This means that modern state power needed to be paramount over all other social, political, or economic agencies. Above all, only it was allowed to possess, in Max Weber's terms, "a monopoly of legitimate violence." Internally, this took the form of the police force and externally, the armed forces.

During the course of the bourgeois revolutions and the establishment of a bourgeois order, the idea of sovereignty had to be redefined. The establishment of the bourgeois order meant that the sovereignty of princes had to be replaced by sovereignty of the people. The change of definition, in other words, was a change 
in the subject of sovereignty, but not in the basic substance of sovereignty-the idea that the nation-state had the final and absolute right to make decisions.

\section{Challenges to sovereignty}

The state's claim to sovereignty, however-i.e., to the final right of decision-is now being relativized in many ways. For centuries it was the privilege of the state to make decisions regarding waging wars on and forging peace with other states on the basis of its national sovereignty. Within this privilege it may have become a matter of common practice to institutionalize more or less binding relationships between sovereign states, either within a system of balance of powers or a system of collective security. But the relativization of the principle of national sovereignty only occurred after 1945. This took three forms:

Internationality. The first genuine limitation on national sovereignty came with the Charter of the United Nations. At the normative level, this eliminated states' sovereign powers with regard to war and the use of force. Renunciation of these powers technically only occurs on a voluntary basis-i.e., without infringing the principle of state sovereignty. But, especially in connection with Chapter VII of the UN Charter on possible collective enforcement measures, the ban on the use of force takes on a significance that effectively curtails the sovereign powers of states. The second Gulf War made this very clear.

Transnationality. The two further ways in which the principle of state sovereignty has been relativized are not associated with any particular date in history, but are rather the result of a slow evolution in modern society.

- Firstly, there has been the development of transnational economic players as a result of the globalization of markets. Global economic players are becoming increasingly independent of national economic policy; the state is increasingly unable to define the political framework for their economic activities. Indeed, the opposite is the case- the global players are themselves creating the ground rules for the state. They can force a state to offer them favorable terms to set up on its territory because the nation-states have allowed themselves to be sucked into the global scramble to attract industry.

- Secondly, in structural terms, the transnational organizations usually referred to as NGOs are in the same position. NGOs illustrate very clearly how far the focus of political action has moved away from national territories and frontiers. Well-known NGOs such as Greenpeace or Amnesty International are no longer concerned about national sovereignty, carrying out their protests where they are required (in the past, even in the Soviet Union). Of course, as the world grows together, there is an increasing consciousness that mankind is growing together as well; in other words, a sense of human solidarity is developing. Some 200 years ago, Immanuel Kant said that, "The community amongst the peoples of the earth has developed to such 
an extent that an infringement of rights in one part of the earth is felt by everybody." This statement, from 200 years ago, has never been more true than today. Infringements of rights in one part of the earth are felt by everybody, and stimulate a feeling of direct political responsibility. And it is this that defines the character of these NGOs: they take political action and thus put into question the state's claim to sovereignty; that is, the state's claim to be able to act without competition. Wherever human rights problems or humanitarian problems occur-as well as environmental problems, starvation and drought, genocide, and mass migration-there are always NGOs operating locally and effectively realizing the right to political participation. And they do so independently of any state claims to sovereignty and any bans on intervention under international law. The nation-states have to come to terms with these social players and reach agreement on how to cooperate with them. In the military sphere, "CIMIC" (Civil-Military Cooperation) has become a model for state military elites.

Supranationality. The third way the principle of nation-state sovereignty has been relativized is the result of the supranational structures that have developed, above all in Europe. Just as the nation-state has passed on some of its decisionmaking powers downwards, to individual members of society, so (at least in Western Europe) it has also ceded a considerable amount of sovereignty upwards, to the European Union. On the other hand, the EU is a highly traditional intergovernmental project based on international law, at least as far as the Council of Ministers and the European Council are concerned. Furthermore, the EU, in the form of the European Commission, is a highly-developed supranational organization whose acquis communautaire has priority over national decisions, as can be seen from the ban on exports of British beef that was imposed against the wishes of the British government.

This supranational removal of state sovereignty is of crucial significance, but the nation-states have in some cases failed to recognize the extent to which they have lost sovereignty.

\section{ON THE PRINCIPLE OF SECULARITY}

Nobody would now disagree that the modern state is a secular one. The religious wars of the seventeenth century effectively demonstrated the shortcomings of religion as a basis for creating political communities. In their aftermath, the private sphere of religion was increasingly separated from the public sphere of politics. The state became secular and no longer derived its legitimacy from a religious or transcendental source. What is more, it only became possible to talk of the "state" in the true sense of the word once the medieval idea of a corpus christianum - a dual, secular and ecclesiastical, leadership of the political community-had dis- 
appeared. But the newly won secularity of the political community now called the "state" created its own problems.

State secularity initially affects the question of how the state functions. It is basically a question of "raison d'etat." The second aspect of the secular state is the question of legitimization: What is a state good for? What prompts people to obey the norms of the state and its "raison d'etat"?

\section{History of ideas: Machiavelli}

At first, following the loss of any religious aspect to political life, the innate logic of politics was discovered. Machiavelli was the inventor of the theory of "raison d'etat," and Frederick II of Prussia was its best-known proponent. The so-called Age of Enlightenment operated basically according to the principle of "raison d'etat." Significantly enough, historian Sebastian Haffner has referred to Prussia as a "rational state" rather than a "nation-state." And, indeed, rationality ruled supreme in Prussia. Everyone was allowed to think, say, and write what one wanted, provided this did not affect the "raison d'etat." The tolerance introduced by the Prussian state was based on indifference towards matters regarded as private, such as language, customs, and religion. The state, however, was not so tolerant when it came to the requirements for its own survival. Machiavelli had provided a devastating list of these required elements. His book Il Principe became a symbol of the new view of political reality. According to Machiavelli, the state operates according to laws-raisons d'etat - that he describes as part of his secularized view of history and the political system.

Secularized view of history. The traditional view of history was determined by the idea of divine providence. The concept of providentia Dei offered a solution to individuals' experience of the confusing discrepancy between political intention and political result, political planning and political outcome, political will and political impact. Responsibility for the difference between what Man wantshis plans and actions-and what emerges as the end result, lies in hands of God rather than Man. With the advent of the modern period, Man becomes responsible for everything, even for the less desirable results of his actions. Machiavelli was a typical example. For him, divine providence had already become secularized, transformed into the operation of so-called blind destiny. However, he regarded it as Man's duty to master this destiny. In other words, fortuna is blind destiny, virtú the strength to oppose it. Only those who are capable of taking their destiny into their own hands possess virtú (Principe XXV: "Fortune is a woman and if she is to be submissive it is necessary to beat and coerce her.... Always, being a woman, she favors young men, because they are less circumspect and more ardent, and because they command her with great audacity"). As this metaphor proves, political virtú has, by its very nature, a propensity for violence. And violence is the medium that guarantees control over the results of actions. 


\section{THE QUARTERLY JOURNAL}

Secularized political system. A propensity for violence also emerges from Machiavelli's concept of a political system. The medieval world only knew political problems in the form of the need to preserve a religious/political legal order. Since the days of Constantine, Christianity had taken over the position and function of the old Polis Religion and had become a public religion that determined all aspects of life. Systematic political problems were thus predefined as problems of preserving such a religiously determined order. A political system that has been freed from divine providence, however, has nothing to preserve except itself. Thus Machiavelli's idea of "raison d'etat" was born, to be understood as the imperative for a state to preserve itself at all costs. Any moral or legal norms realized within the political system are effectively dependent on the state's ability to preserve itself both internally and externally. In this way, the state necessarily came to be based on might. The primary problem of the state is therefore the problem of coping with potential threats to its existence, i.e. the possibility of disappearing from the political map. It should be clear from this that the state therefore has to be judged by its ability to wage war. Military power thus becomes the ultima ratio regis.

However, Machiavelli made a typical additional assumption. According to him, history does not move in a straight line but is cyclical. By claiming this, he supplied a strong motive for state expansionism. For as long as states are on the ascendant, Machiavelli argues, they have to operate in a bellicose manner. But when their military power is on the decline, and art and science begin to dominate, states are, according to him, already on the way out in historical terms. This bellicose concept of the state of course destroys any idea of a just war. All that is important in the modern period is that the state secures its own survival in the general conflict between expanding states. This can also be seen from the reinterpretation of the traditional political idea of the unity of peace, justice, and harmony (pax, justitia, and concordia). For Machiavelli, peace has become a question of power, that is, a question of access to sufficient military resources to deter one's opponent. Justitia and concordia are ruthlessly functionalized in a similar way. They are not the justification for the state; indeed the opposite is the case-the state justifies them, and only a powerful state lends them validity.

Integration of the community: Christianity-civil religion-nationalism. Of course, the citizens have to go along with this new structure of the state by demonstrating the necessary obedience. Machiavelli was aware of this problem. Thus, in his Discorsi (I, 11) he stated with regard to the Roman republic in the days of classical antiquity: "Numa Pompilius, finding a very ferocious people and wanting to reduce them to civil obedience by the acts of peace, turned to religion as something completely necessary in wanting to maintain a civilization.... Whoever considers well Roman history will see how much Religion served in commanding the armies, in reuniting the plebeians, both in keeping men good, and in making the wicked ashamed." Assuming that the existence of such a civil religion is rec- 
ognized as necessary, he was, however, also capable of expressing criticism of Christianity: "If our religion claims of us fortitude of soul, it is more to enable us to suffer than to achieve great deeds. These principles seem to me to have made men feeble, and caused them to become an easy prey to evil-minded men" (Discorsi II, 2). Thus, according to Machiavelli, Christianity is not suited to political functionalization.

Inasmuch, however, as the secular "raison d'etat" cannot survive without a degree of normative legitimization, it would appear that nationalism, as a civil religion, has increasingly filled the gap left behind by religion once it lost its political function. Nationalism, however, only appeared towards the end of the Age of Enlightenment. But its discovery was a logical step. "Raison d'etat" might have found an appropriate response to the question of the immanent functional imperative of the state, but it did not find an answer to the question of its legitimacy. With the rise of the nineteenth-century idea of the nation state, this question could now be answered. Its legitimacy consisted above all in its role of offering security to the nation but also in increasing the nation's prosperity and promoting its culture. National armed forces were created, national economies established themselves, and national cultures began to flourish. The effects of such nationalism differed according to whether one looked forwards or backwards, inwards or outwards.

Looking backwards, nationalism tended to "fundamentalize" nations. They increasingly felt they had national roots, that their feelings wishes and actions were rooted in common history, provenance, and language.

Looking forwards, nationalism provided people with a vision and sense of mission. The "place in the sun" sought by Germany is just as revealing in this context as Wilson's intention "to make the world safe for democracy."

Looking inwards, nationalism "homogenized" nations and legitimized political action in the so-called national interest: "my country, right or wrong."

Looking outwards, nationalism polarized relations between nations; they became alienated from one another and from now on failed to understand one another. This mutual alienation encouraged war as a way of providing relief.

Thus a large degree of correspondence between the imperatives of "raison d'etat" and nationalism developed, which was of extreme significance for the wars waged in the twentieth century. The idea of a powerful state and the idea of nationalism are not identical, but there is a fruitful affinity between them.

\section{Multicultural challenges}

At the end of the 20th century, however, this congruence between secular "raison d'etat" and secular nationalism has been put into question. The crucial concept here is multiculturalism. In empirical and social terms, multiculturalism means that there is no homogeneous cultural "model" on which the state is based. In all countries of Europe, established national cultures are increasingly being enriched 
and augmented. Refugee and migration movements on the one hand, and internationalization of the labor market on the other, are producing a degree of cultural differentiation in Europe that has never existed in the past. This is also partly the result of the fact that many Europeans have found meaning in various spiritual and medical doctrines of the Far East. All this ensures the presence of such a wide range of cultural alternatives that it is increasingly difficult to gain a proper overview.

In political terms, multiculturalism means that various groups are articulating claims with regard to their collective identities. They claim the right to make public their particular group identity, either through wearing special clothes, observing special holidays, practicing special definitions of gender roles, adopting a particular religious architecture, or observing particular religious rituals, etc. The question now becomes how the traditional nation state has to be modified so as to fulfill its integrative function under multicultural conditions. At present a trend can be observed whereby national cultures are being replaced by "milieu" cultures, e.g., a fundamentalist milieu culture, a traditionalist one, and the modernist one. As Thomas Meyer noted, "There is an increasing mismatch between the external boundaries of socio-cultural milieus-which are in any case extremely permeable - and geographical territories." This being the case, then, it becomes impossible to speak of European culture but rather only of globalized milieu cultures. Furthermore, these milieu cultures also have a tendency to create mutually exclusive boundaries in both the national and global contexts. The question of how the state can offer a degree of normative integration may thus be moot. Post-national conditions, when it comes down to it, are also post-state conditions. The development has started. There is no end in sight. 